\title{
SOLAR AVAILABILITY FOR WINTER SPACE HEATING: AN ANALYSIS OF THE CALENDAR PERIOD 1953-1975
}

\author{
by
}

J. G. Asbury, C. Maslowski, and R. 0. Mueller

\section{MASTER}

SPECIAL PROJECTS GROUP • ENERGY AND ENVIRONMENTAL SYSTEMS DIVISION

PREPARED FOR THE UNITED STATES

DEPARTMENT OF ENERGY Under Contract W-31-109-Eng-38

\author{
ARGONNE \\ NATIONAL \\ LABORATORY
}


The facilities of Argonne National Laboratory are owned by the United States Government. Under the terms of a contract (W-31-109-Eng-38) among the U. S. Department of Energy, Argonne Universities Association and The University of Chicago, the University employs the staff and operates the Laboratory in accordance with policies and programs formulated, approved and reviewed by the Association.

\section{MEMBERS OF ARGONNE UNIVERSITIES ASSOCIATION}

The University of Arizona Carnegie-Mellon University Case Western Reserve University The University of Chicago University of Cincinnati Illinois Institute of Technology University of Illinois Indiana University The University of Iowa Iowa State University
The University of Kansas

Kansas State University

Loyola University of Chicago

Marquette University The University of Michigan

Michigan State University

University of Minnesota

University of Missouri

Northwestern University

University of Notre Dame
The Ohio State University

Ohio University

The Pennsylvania State University

Purdue University

Saint Louis University

Southern Illinois University

The University of Texas at Austin

Washington University

Wayne State University

The University of Wisconsin-Madison

This report was prepared as an account of work sponsored by an agency of the United States Government. Neither the United States nor any agency thereof, nor any of their employees, makes any warranty, expressed or implied, or assumes any legal liability or responsibility for any third party's use or the results of such use of any information, apparatus, product or process disclosed in this report, or represents that its use by such third party would not infringe privately owned rights. Mention of commercial products, their manufacturers, or their suppliers in this publication does not imply or connote approval or disapproval of the product by Argonne National Laboratory or the United States Government.

Printed in the United States of America

Available from

National Technical Information Service

U. S. Department of Commerce

5285 Port Royal Road

Springfield, VA 22161

NTIS price codes

Printed copy: A02

Microfiche copy: A01 


\section{DISCLAIMER}

This report was prepared as an account of work sponsored by an agency of the United States Government. Neither the United States Government nor any agency Thereof, nor any of their employees, makes any warranty, express or implied, or assumes any legal liability or responsibility for the accuracy, completeness, or usefulness of any information, apparatus, product, or process disclosed, or represents that its use would not infringe privately owned rights. Reference herein to any specific commercial product, process, or service by trade name, trademark, manufacturer, or otherwise does not necessarily constitute or imply its endorsement, recommendation, or favoring by the United States Government or any agency thereof. The views and opinions of authors expressed herein do not necessarily state or reflect those of the United States Government or any agency thereof. 


\section{DISCLAIMER}

Portions of this document may be illegible in electronic image products. Images are produced from the best available original document. 
Distribution Category:

Heating and Cooling -

Research and Development (UC-59c)

ANL/SPG- 14

ARGONNE NATIONAL LABORATORY

9700 South Cass Avenue

Argonne, Illinois 60439

SOLAR AVAILABILITY FOR WINTER SPACE HEATING:

AN ANALYSIS OF THE CALENDAR PERIOD 1953-1975

by

J. G. Asbury, C. Maslowski, and R. O. Mueller

Energy and Environmental Systems Division

April 1979

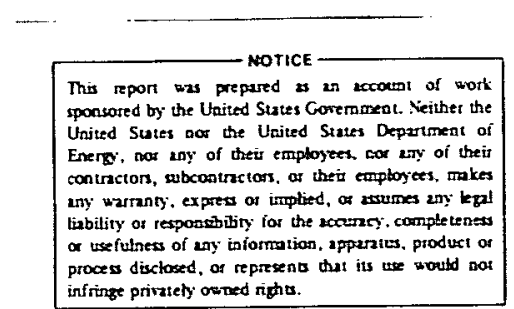

Work Supported by

U.S. DEPARTMENT OF ENERGY

Assistant Secretary for Energy Technology

Division of Energy Storage Systems 


\footnotetext{
$$
7
$$
}

7 .

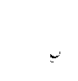

4 . 
ABSTRACT. . . . . . . . . . . . . . . . . . . . . . . . 1

1 INTRODUCTION AND SUMMARY . . . . . . . . . . . . . . . . . . . . . 1

2 DESCRIPTION OF SOLMET DATA . . . . . . . . . . . . . . . . . . . . 2

3 Data ANAlysis. . . . . . . . . . . . . . . . . . . . . . . . . . . 3

4 BACKUP REQUIREMENTS FOR SOLAR HEATING SYSTEMS. . . . . . . . . . . 4

5 SUMMARY RESULTS. . . . . . . . . . . . . . . . . . . . . 10

REFERENCES. . . . . . . . . . . . . . . . . . . . . 15

\section{FIGURES}

1 Daily Insolation vs Heating Degree-Days

Albuquerque . . . . . . . . . . . . . . . . . . . . 5

Bismark . . . . . . . . . . . . . . . . . . . . . 5

Boston . . . . . . . . . . . . . . . . . . . . . . 6

Caribou . . . . . . . . . . . . . . . . . . . 6

Columbia . . . . . . . . . . . . . . . . . . . . . . 7

Madison . . . . . . . . . . . . . . . . . . . . . . . . . . . . . 7

Seattle . . . . . . . . . . . . . . . . . . . 8

Sterling... . . . . . . . . . . . . . . . . . . . 8

2 Daily Insolation vs Heating Degree-Days for Columbia, Missouri, at a Collector Tilt Angle Equal to Latitude plus $20^{\circ}$. . . . . . . 9

3 Load Duration Curves of Daily Backup-Energy Requirements Albuquerque . • . . . . . . . . . . . . . . . . . . . . . 11 Bismark . . . . . . . . . . . . . . . . . . . . . . . . . . 11 Boston . . . . . . . . . . . . . . . . . . . . . . . . . 12 Caribou . . . . . . . . . . . . . . . . . . . . . . . . . 12 Columbia . . . . . . . . . . . . . . . . . . . . . . . . . . . . 13 Madison . . . . . . . . . . . . . . . . . . . . . . . . . . . 13 Seattle . . . . . . . . . . . . . . . . . . . . . . . 14 Sterling . . . . . . . . . . . . . . . . . . . . . . . . . . . . 14

TABLE

1 Ratio of Building Heating Requirement to Collector Area . . . . 10 
SOLAR AVAILABILITY FOR WINTER SPACE HEATING:

AN ANALYSIS OF THE CALENDAR PERIOD 1953-1975

by

J.G. Asbury, C. Maslowski, and R.0. Mueller

\begin{abstract}
Solar availability for space heating has been determined from an analysis of SOLMET data tapes for eight U.S. sites. The tapes contain hourly readings of insolation and ambient temperature for the period 1953-1975. Scatter-diagrams of insolation versus heating degree-days, compiled on a daily basis, indicate a wide variation in insolation levels, even during periods of coldest weather. For seven of the eight sites, the peak-day backup energy required by a solar space heating system exceeded $85 \%$ of the peak-day energy requirement of a conventional (nonsolar) heating system.
\end{abstract}

\title{
1 INTRODUCTION AND SUMMARY
}

The day-to-day variation in insolation observed at most locations in the United States is a serious problem facing designers of solar heating systems. In most solar energy applications, an auxiliary, or backup, system is required if the heating load is to be met reliably during extended periods of cloud cover. In space heating applications, this usually means the addition of a backup furnace capable of supplying the design-day heating load. Although the cost of the auxiliary system, by itself, is usually a relatively minor component of the total system's capital cost, the cost of supplying energy to the backup system can be high. In particular, if the backup energy is electricity, the demand component of the cost, including the electric utility's investment in "standby" generation and distribution capacity, can be substantial. 1

The impact of space heating on the electric utility's capacity requirements depends upon whether the utility's peak load occurs during the winter or the summer. If the utility is summer-peaking, neither a solar nor conventional heating system will contribute to the utility's generation and transmission capacity requirements. On the other hand, if the utility is winter-peaking, its capacity expansion requirement will be largely determined by the peak space heating loads. In this case, the impact of a solar heating system may differ significantly from that of a conventional system, depending upon the level of insolation on the coldest winter days. ${ }^{2}$

Two recent studies examined solar availability on peak heating days. A study of the Philadelphia area concluded that a solar heating system's auxiliary power requirements were the same as the total requirements of a

*To a lesser extent, this is also a problem for the natural gas distribution system. 
conventional furnace. ${ }^{3}$ Another study simulated the peak-period performance of both solar heating and solar cooling systems at several U.S. locations. At the two northern sites, in New England and Wisconsin, there was evidence of substantial solar availability on peak heating days. 4 This led to speculation that, in certain climatic regions, there may be a correlation between high insolation levels and low outdoor temperatures. A more conclusive assessment of the solar availability question would require additional data from more sites, collected over longer periods of time.

The release of the SOLMET data tapes by the National Climatic Center in early 1978 provided an opportunity to examine insolation levels at a number of U.S. locations for a period of more than two decades, from 1953 to 1975.5 The results presented in this paper are based upon analyses of the SOLMET data for eight representative U.S. sites. Solar availability and daily heating requirements were examined on a seasonal and coldest-days basis. The data were displayed in two general formats.

First, SOLMET data for insolation and heating degree-days were compiled on a daily basis and the results for each site presented in scatterdiagrams. The plots encompass the full calendar period available in the SOLMET data and give a simple visual display of the relationship between daily insolation and daily average temperature. As these plots make clear, the correlation between daily insolation and daily average temperature is weak for all sites, over both the full heating season and the subset of coldest days. Second, a simple model of solar collector performance was used to calculate the daily output of a solar heating system. The daily backup requirements for solar energy systems and the daily power needs of conventional heating systems were then computed and the results presented in the form of load duration curves. Except for one site, in Albuquerque, the addition of solar space heating systems did not significantly reduce the electric utility's capacity requirement. The peak-day backup requirement of a solar energy system sized to supply $50 \%$ of the annual space heating load usually exceeded $85 \%$ of the peak-day electrical requirement of a nonsolar heating system.

\section{DESCRIPTION OF SOLMET DATA}

The SOLMET data are the product of an extensive "rehabilitation" of hourly solar radiation data by the National Climatic Center. 5 Data tapes are now available from 26 weather stations across the United States. For most locations the period of record extends from July 1, 1952, to December 31, 1975.

The tapes contain hourly readings of global solar radiation incident on a horizontal surface and instantaneous measurements of certain surfaceweather variables, including wind speed, atmospheric pressure, and ambient temperature. The recorded insolation is the total of direct and diffuse radiation received on a pyranometer, integrated over the hour.

In addition to the raw solar-radiation data, the SOLMET tapes contain two types of rehabilitated radiation data: "engineering-corrected" and "standard-year-corrected" data. The engineering-corrected data incorporate corrections for all recorded scale and calibration changes. Although more 
accurate than the observed data, these data include unrecorded and undetected systematic errors.

To correct for long-term, undetected changes in sensor or recorder response, the $\mathrm{Climatic}$ Center constructed the standard-year-corrected data. By comparing the observed values of solar radiation on clear weather days with predicted values from a standard-year irradiance model, the Climatic Center calculated correction factors that were then used to normalize all of the hourly insolation readings. We calculated the root-mean-square values of the correction factors for hourly insolation over all years of data for each of the eight sites. The values ranged from 0.05 to 0.10 .

Due to malfunctions of the sensors and recording instruments, the SOLMET tapes have gaps in observed insolation data for periods extending over days, weeks, and even months. To fill these gaps, the Climatic Center estimated hourly solar radiation levels from measurements and observations of opaque cloud cover, precipitation, and minutes of sunshine per hour. These estimates were added to the standard-year-corrected field to make it serially complete.

\section{DATA ANALYSIS}

The $\mathrm{Cl}$ imatic Center recommends the standard-year-corrected data as the most reliable of the data fields. Accordingly, the results presented in this paper are based on these data. A complete description of the raw data and the techniques and procedures used to construct the standard-yearcorrected data are presented in the SOLMET manuals. 6

Data from eight sites are presented here. These sites, selected to span the range of climatic and geographic conditions of locations with solar-space-heating potential in the United States, are:

- Albuquerque, New Mexico;

- Bismark, North Dakota;

- Boston, Massachusetts;

- Caribou, Maine;

- Columbia, Missouri;

- Madison, Wisconsin;

- Seattle, Washington; and

- Sterling, Virginia.

The only modification to the standard-year-corrected data was to adjust insolation to take collector tilt into account. Adjusted insolation values were computed using the standard Liu and Jordon relation for dividing the global insolation into diffuse and direct components. The diffuse component was assumed to be isotropic, and the direct component was estimated by simple cosine projection onto the collector surface.? 
Plots of insolation on the collector surface versus heating degreedays are shown for individual days at each site in Fig. 1. The heating degree-day values are calculated relative to a $65^{\circ} \mathrm{F}$ reference temperature. The collector tilt angle for each site is set equal to the latitude of the site. The points in the scatter-diagrams correspond to all days within the 23-year period from January 1, 1953, through December 31, 1975.* In constructing the plots, we imposed somewhat arbitrary degree-day cutoffs of $10^{\circ} \mathrm{F}$ on the northern sites and $0^{\circ} \mathrm{F}$ on the more southern sites. The effect of a change in collector tilt to an angle equal to latitude plus $20^{\circ}$ is shown in Fig. 2 for the Columbia, Missouri, site.

All the scatter-diagrams indicate a wide variation in insolation levels for each degree-day value. Even the subset of the 230 coldest days at each site includes a number of days with insolation levels less than $20 \%$ of the clear-day level for that site.

To obtain a quantitative measure of the correlation between solar availability and temperature on the coldest days, we performed a leastsquares linear regression of daily insolation on daily degree-days for the coldest 230 days for each site. The calculated correlation coefficients ranged from -0.0044 for Bismark, North Dakota, to +0.189 for Seattle, Washington. When the data sample was not restricted to the coldest days, but was expanded to include all days with a space heating requirement, the correlation coefficients were found to be negative for all of the sites.

\section{BACKUP REQUIREMENTS FOR SOLAR HEATING SYSTEMS}

During cold periods, when the daily heating load exceeds solar collector output, most solar energy systems deliver available solar energy to the load with little or no day-to-day carryover of stored energy. To calculate the backup energy requirements for the coldest days, we adopted a simple model of solar collection that assumed no storage carryover.

This model is applicable to solar heating systems that incorporate storage with capacity approximately equal to one day's collector output. The analysis does not apply to solar energy systems with storage capacities capable of meeting heating loads during extended (multi-day) periods of cloudy weather. In particular, it does not apply to seasonal solar heating concepts, that is, those systems in which solar energy is collected during summer months and stored for use during the winter heating season.

Collector performance was modeled with the Hottel-Whillier equation. A standard hydronic flat-plate collector, with a heat loss of $17 \mathrm{~kJ} / \mathrm{m}^{2}-{ }^{\circ} \mathrm{C}-\mathrm{hr}$ and an absorptance transmittance product of 0.73 , was used. On the coldest days, collected energy passes rapidly to the load, with storage temperature and collector-inlet temperature remaining at relatively low values, as determined by the minimum temperature requirements of the load. The constant value of $90^{\circ} \mathrm{F}$ selected here for the collector-inlet temperature is suitable for space heating and will yield an optimistic estimate of collected solar energy.

*For Boston, Massachusetts, the period is 16 years, from January 1, 1953,

to December 31, 1968; for Sterling, Virginia, 22 years, from January 1, 1954, to December 31, 1975. 

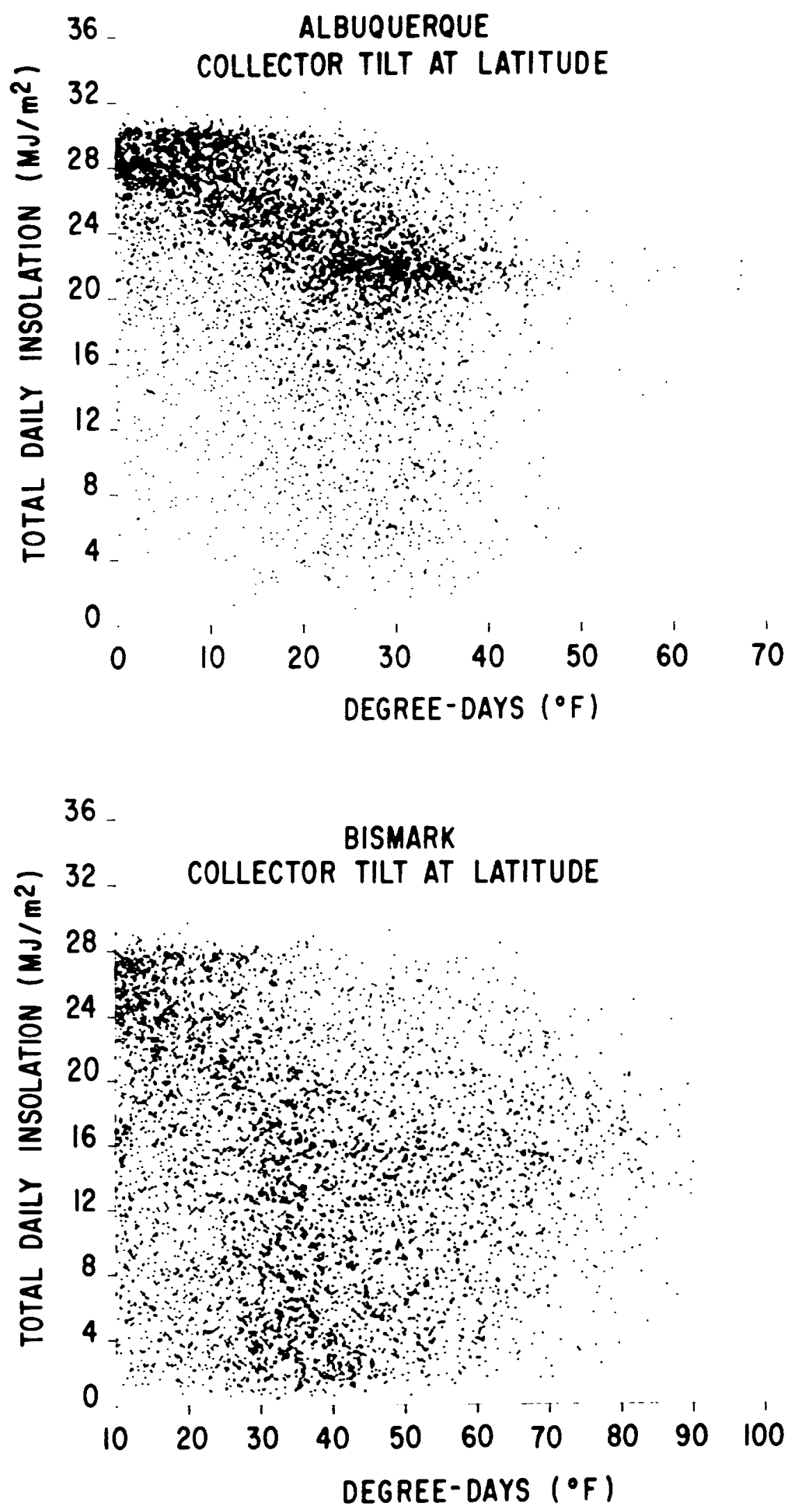

Fig. 1. Daily Insolation vs Heating Degree-Days 

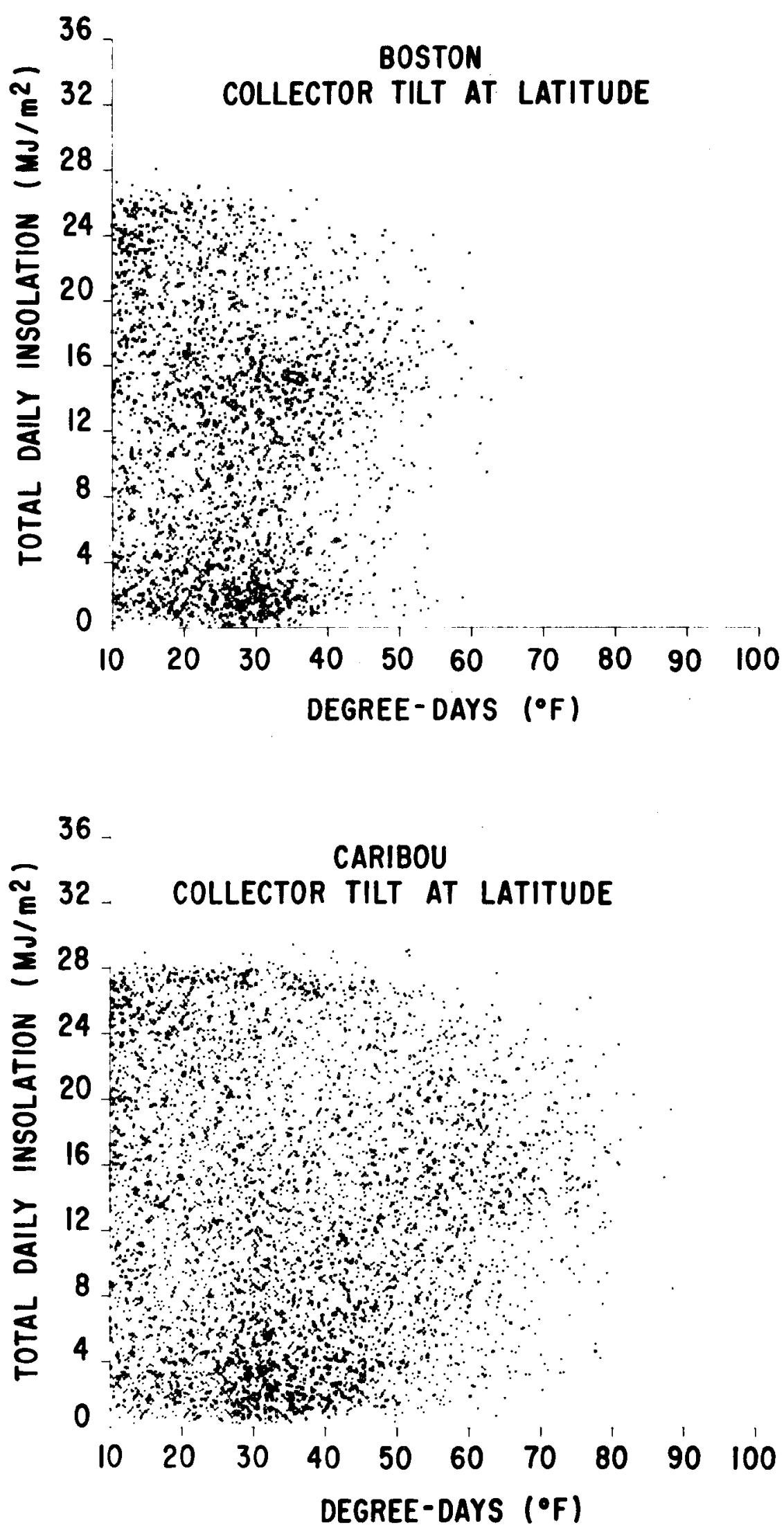

Fig. 1. Daily Insolation vs Heating Degree-Days (Cont'd) 

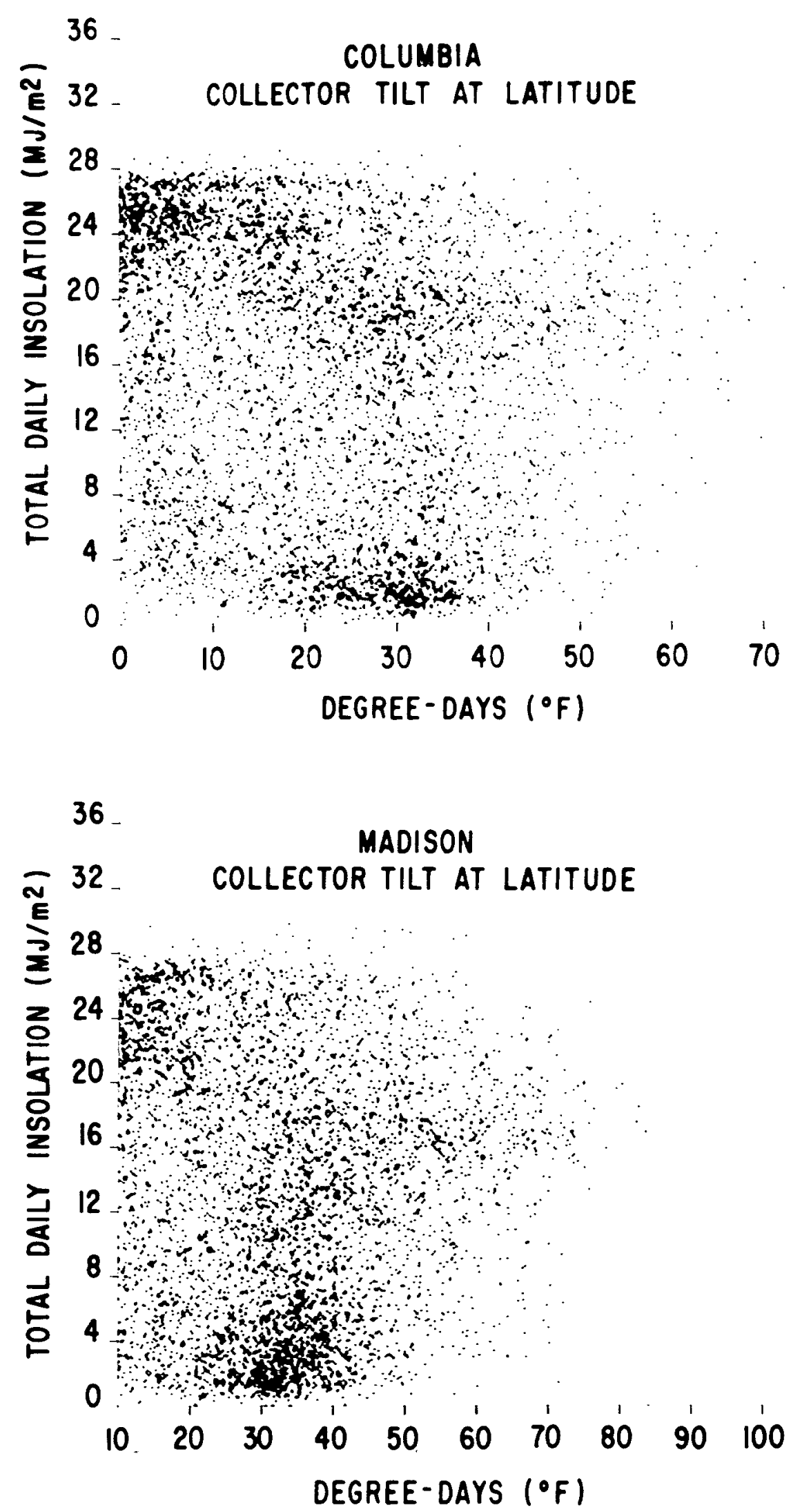

Fig. 1. Daily Insolation vs Heating Degree-Days (Cont'd) 

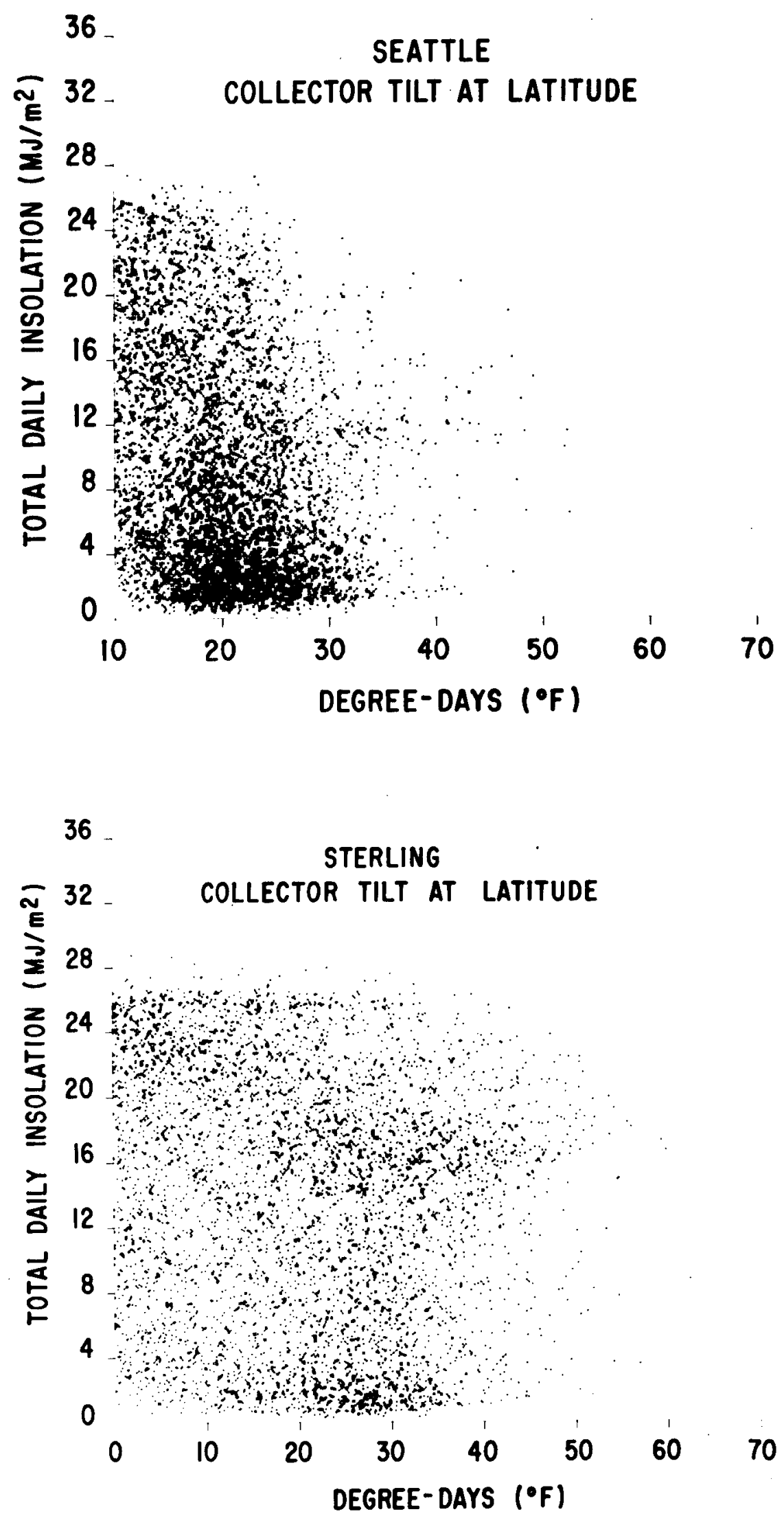

Fig. 1. Daily Insolation vs Heating Degree-Days (Cont'd) 


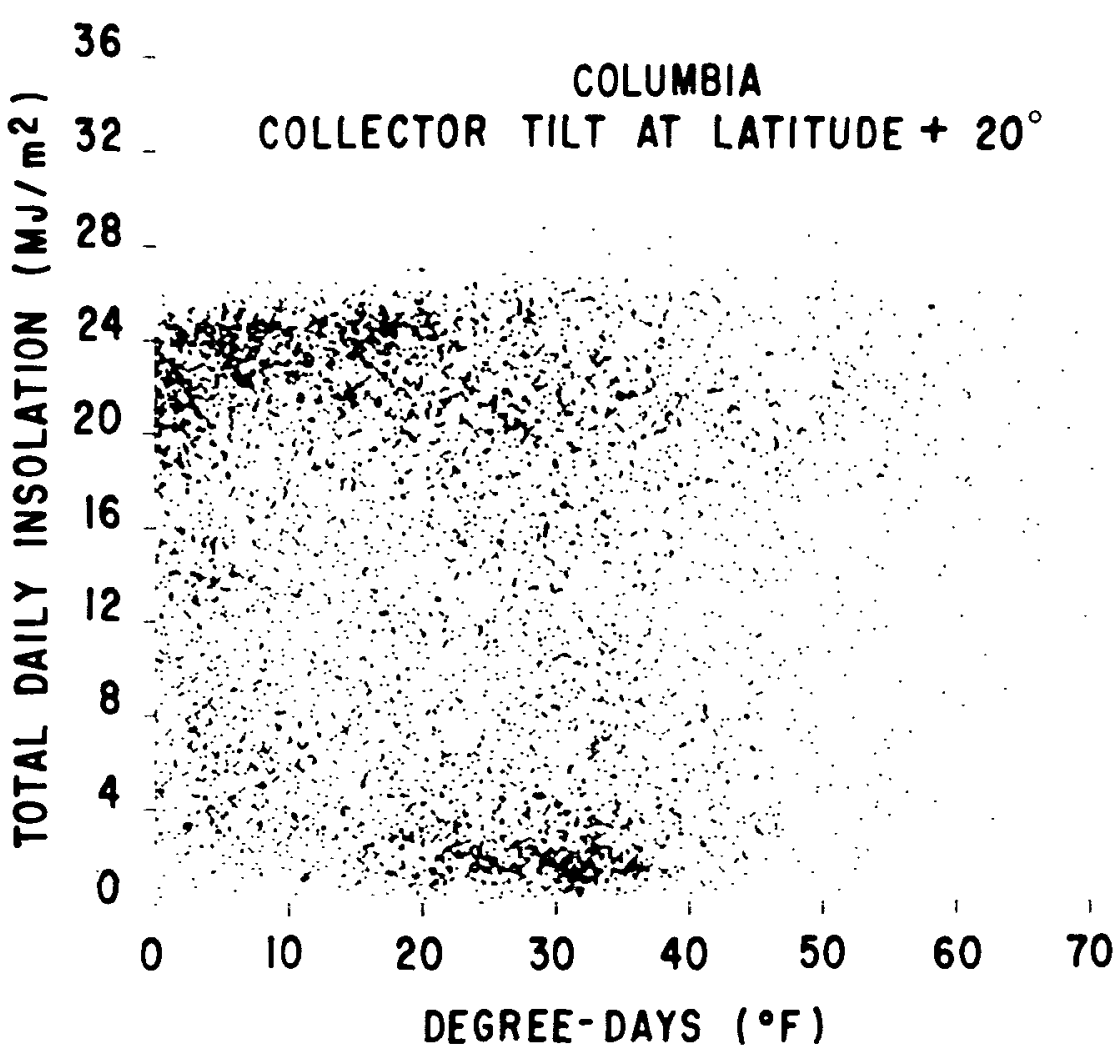

Fig. 2. Daily Insolation vs Heating Degree-Days for Columbia, Missouri, at a Collector Tilt Angle Equal to Latitude plus $20^{\circ}$

At each location, collected solar energy was estimated on a daily basis for three array sizes. Table 1 gives the ratios of building heating requirements to collector areas for solar systems designed to supply $25 \%$, $50 \%$, and $75 \%$ of the annual heating load. 8 By comparing the availability of solar energy with total heating requirements on a daily basis, we then computed the daily backup-energy requirements for the solar heating systems. The resulting load-duration curves (cumulative frequency distributions) of daily backup-energy requirements are shown for each site in Fig. 3. The curve labeled "0\%" corresponds to conventional heating systems and the other three curves to solar heating systems sized to meet $25 \%, 50 \%$, and $75 \%$ of the annual heating load.

As indicated in each figure the backup energy requirement is normalized to the maximum daily heating load observed over the SOLMET period of record (usually one day in 23 years). With this normalization, the solar system's backup requirement depends only on the ratio of the building heating requirement to the collector area. Along the horizontal axis, the number of occurrences is divided by the number of years of data to normalize to a one-year cycle. Because the calculation of solar output is based on the assumption of no day-to-day storage carryover, it is strictly accurate only for the subset of coldest days. The dashed portions of the curves show the results of continuing the same calculational procedure over all days with a positive heating load. The logarithmic scale along the horizontal axis provides greater detail over the period of coldest days. 
Table 1. Ratio of Building Heating Requirement to Collector Area [( Btu/degree-day)/ft $\left.{ }^{2}\right]^{a}$

\begin{tabular}{lrrr}
\hline \multirow{2}{*}{ Site } & $\begin{array}{r}\text { Solar Fraction of } \\
\text { Annual }\end{array}$ & Heating Load b \\
\cline { 2 - 4 } & $25 \%$ & $50 \%$ & $75 \%$ \\
\hline Albuquerque & 161 & 64 & 31 \\
Bismark & 78 & 29 & 14 \\
Boston & 86 & 33 & 16 \\
Caribou & 68 & 26 & 12 \\
Columbia & 102 & 38 & 18 \\
Madison & 76 & 28 & 13 \\
Seattle & 94 & 33 & 13 \\
Sterling & 111 & 43 & 21 \\
\hline a Source: Ref. 8. & \multicolumn{3}{c}{} \\
b Solar fractions pertain to a collector with \\
the characteristics described in the text. To \\
obtain collector area (in ft ${ }^{2}$ ), divide heating \\
requirement (in Btu/degree-day) by the ratio \\
given in the table.
\end{tabular}

Except for the Albuquerque site, there is little reduction in backup requirements of the solar heating systems relative to the capacity requirements associated with conventional (nonsolar) heating systems. Even for solar heating systems sized to supply $75 \%$ of the annual space heating load, backup requirements usually exceed $85 \%$ of the peak-day requirement for the nonsolar system. For Albuquerque, the capacity reductions were approximately $10 \%, 18 \%$, and $25 \%$ for solar heating systems sized to supply $25 \%, 50 \%$, and $75 \%$ of the annual heating load, respectively.

\section{RESULTS}

Using recently-released SOLMET data tapes, we have examined solar availability for space heating at eight U.S. sites. Scatter-diagrams of insolation versus heating degree-days, compiled on a daily basis, indicate a wide variation of insolation levels. The correlation between daily insolation and daily average temperature is weak for all of the sites examined, over both the full heating season and the subset of coldest days.

A simple model of solar collector performance was used to compare solar heating system output with daily space heating loads to obtain the daily backup-energy requirements. Underlying the model is the assumption that no day-to-day storage carryover occurs during the coldest periods. This is appropriate for the large class of solar heating systems with storage capacities less than or equal to one day of solar collector output. Except in Albuquerque, the backup energy requirements of the solar heating systems were found to exceed $85 \%$ of the peak-day energy requirements of the conventional heating systems. 

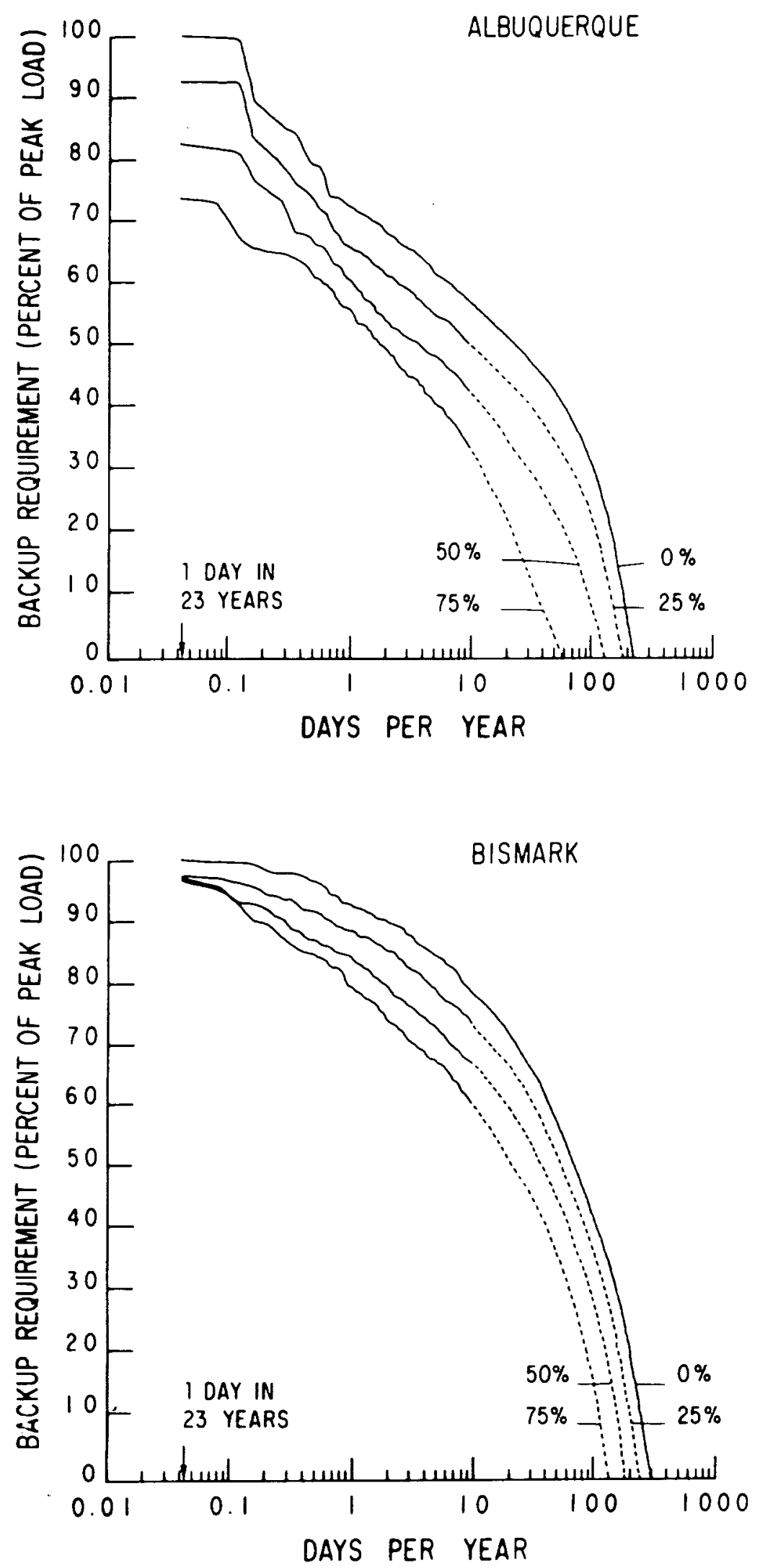

Fig. 3. Load Duration Curves of Daily Backup-Energy Requirements 

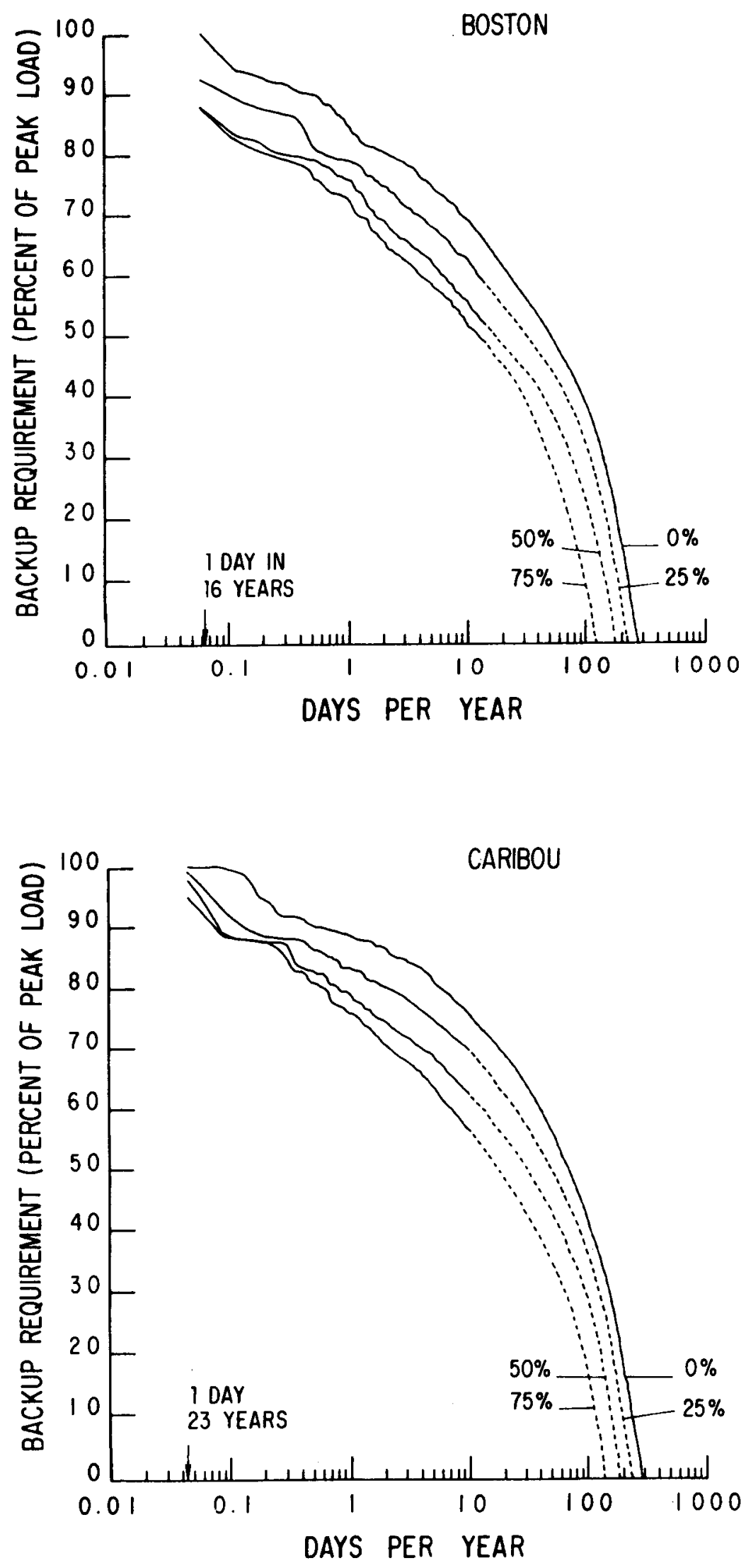

Fig. 3. Load Duration Curves of Daily Backup-Energy Requirements (Cont'd) 

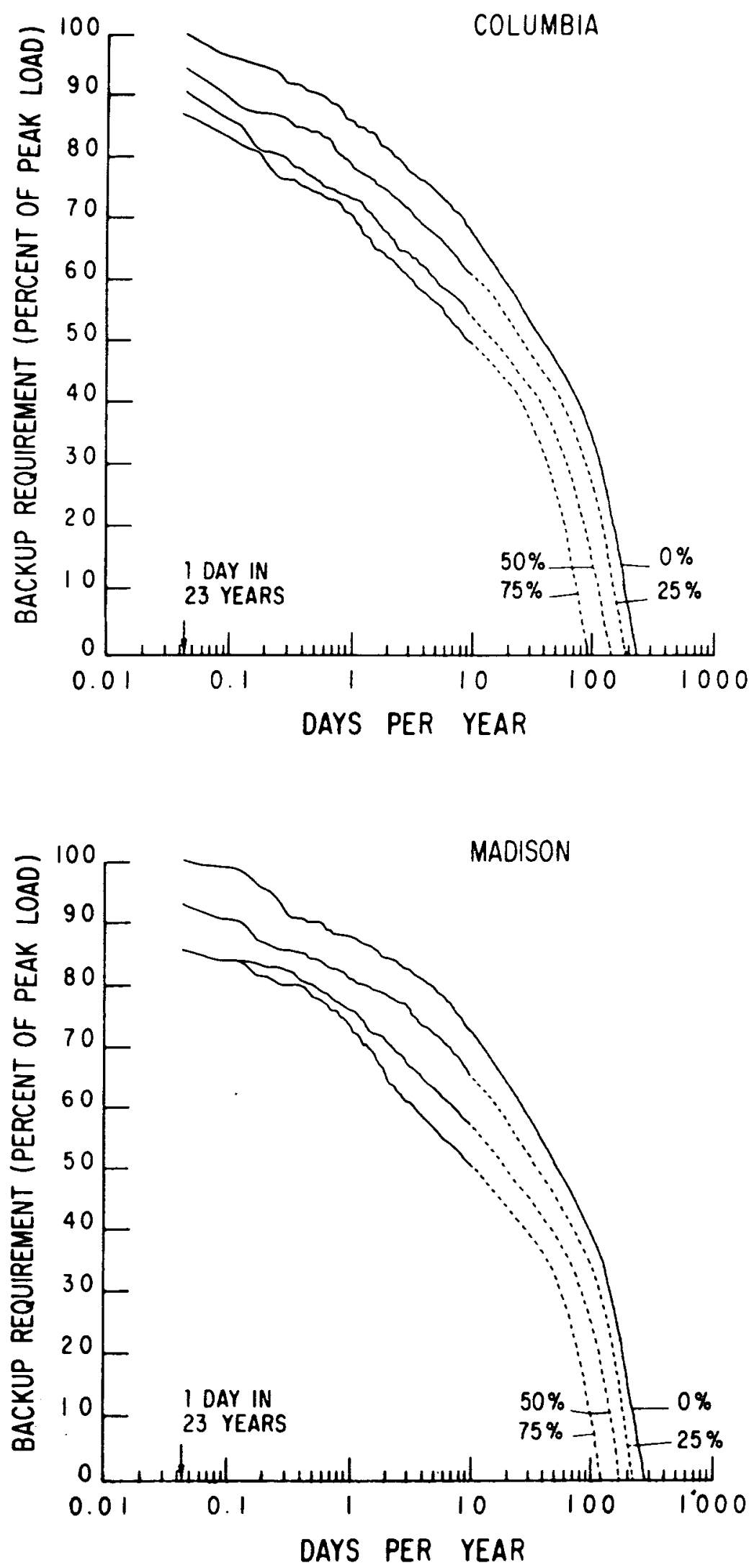

Fig. 3. Load Duration Curves of Daily Backup-Energy Requirements (Cont'd) 

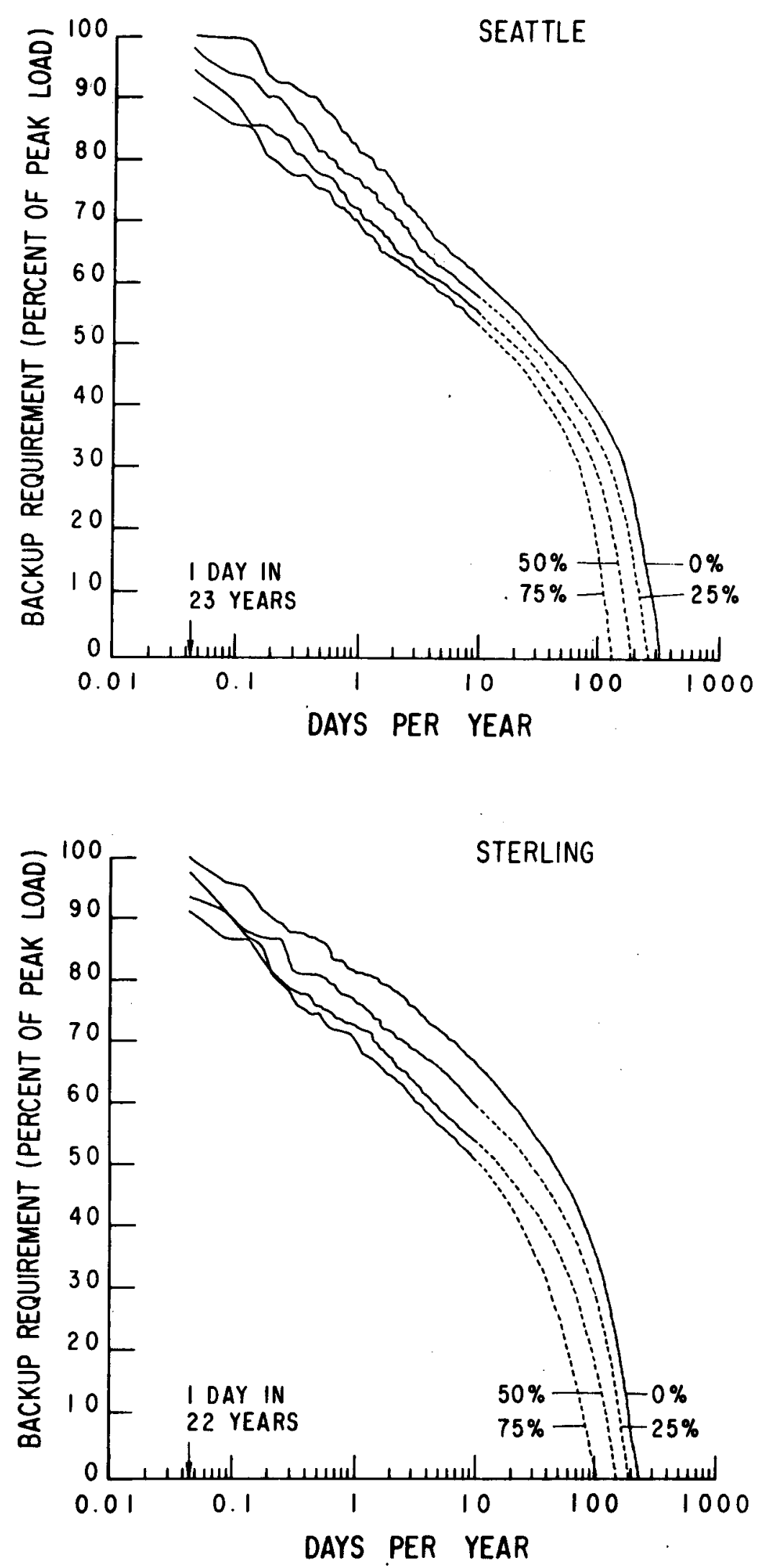

Fig. 3. Load Duration Curves of Daily Backup-Energy Requirements (Cont'd) 


\section{REFERENCES}

1. Asbury, J.G., and R.0. Mueller, Solar Energy and Electric Utilities: Should They Be Interfaced?, Science, 195:445 (1977).

2. Asbury, J.G., R.F. Giese, and R.0. Mueller, Space Heating with Electricity: The Promise of Peak-Load Pricing, accepted for publication in Technology Review.

3. Lorsch, H., Implications of Residential Solar Space Conditioning on Electric Utilities, Franklin Institute Research Laboratories, final report prepared for National Science Foundation under contract NSF-C1033 (Dec. 1976).

4. Feldman, S.L., et al., Utility Pricing and Solar Energy Design, Clark University, final report prepared for National Science Foundation under contract NSF/RANN APR-75-18006 (Sept. 1976).

5. SOLMET data tapes; prepared by U.S. Department of Commerce, National Oceanic and Atmospheric Administration, Environmental Data and Information Service, National Climatic Center; Asheville, North Carolina; for U.S. Department of Energy (1978).

6. U.S. Department of Commerce, SOLMET, Volume 1 - User's Manual and SOLMET, Volume 2 - Final Report, prepared for U.S. Department of Energy under contract E(49-26)-1041, Asheville, North Carolina (Dec. 1977).

7. Klein, S.A., et al., TRNSYS - A Transient Simulation Program, Version 9.1, prepared by Solar Energy Laboratory, University of Wisconsin, for National Science Foundation and U.S. Department of Energy (Oct. 1977).

8. Balcomb, J.D., and J.C. Hedstrom, The Basics: Sizing Collector Systems, Solar Engineering, 2:18 (1977). 
INTERNAL :

$\begin{array}{lll}\text { J.G. Asbury (120) } & \text { M.L. Kyle } & \text { J.J. Roberts } \\ \text { E.J. Croke } & \text { K.S. Macal } & \text { W.W. Schertz } \\ \text { P.F. Gustafson } & \text { C. Maslowski } & \text { N.F. Sather } \\ \text { W. Harrison } & \text { W.E. Massey } & \text { W.K. Sinclair } \\ \text { L.J. Hoover } & \text { R.O. Mueller } & \text { ANL Contract Copy } \\ \text { A.S. Kennedy } & \text { P.A. Nelson } & \text { ANL Libraries (5) } \\ \text { A.B. Krisciunas } & \text { E.G. Pewitt } & \text { TIS Files (6) }\end{array}$

\section{EXTERNAL :}

DOE-TIC, for distribution per UC-59c (334)

Manager, Chicago Operations and Regional Office, DOE

Chief, Office of Patent Counsel, DOE-CH

President, Argonne Universities Association

Energy and Environmental Systems Division Review Committee:

E.E. Angino, U. Kansas

R.E. Gordon, U. Notre Dame

W.W. Hogan, Harvard U.

L.H. Roddis, Jr., Charleston, S.C.

G.A. Rohlich, U. Texas at Austin

R.A. Schmidt, Electric Power Research Institute

J.H. Gibbons, Office of Technology Assessment, U.S. Congress

D.E. Kash, USGS, Reston, VA 